Determination of Mercury in Aqueous and Geologic Materials by Continuous Flow-Cold Vapor-Atomic Fluorescence Spectrometry (CVAFS)

Techniques and Methods 5-D2 


\section{Determination of Mercury in Aqueous and Geologic Materials by Continuous Flow-Cold Vapor-Atomic Fluorescence Spectrometry (CVAFS)}

By Philip L. Hageman

Chapter 2

Section D, Geologic Analysis

Book 5, Laboratory Methods and Analysis

Techniques and Methods 5-D2 


\section{U.S. Department of the Interior DIRK KEMPTHORNE, Secretary}

\section{U.S. Geological Survey \\ Mark D. Myers, Director}

\section{U.S. Geological Survey, Reston, Virginia: 2007}

For product and ordering information:

World Wide Web: http://www.usgs.gov/pubprod

Telephone: 1-888-ASK-USGS

For more information on the USGS - the Federal source for science about the Earth,

its natural and living resources, natural hazards, and the environment:

World Wide Web: http://www.usgs.gov

Telephone: 1-888-ASK-USGS

Any use of trade, product, or firm names is for descriptive purposes only and does not imply endorsement by the U.S. Government.

Although this report is in the public domain, permission must be secured from the individual copyright owners to reproduce any copyrighted material contained within this report.

Suggested citation:

Hageman, P.L., 2007, Determination of mercury in aqueous and geologic materials by continuous flow-cold vapor-atomic fluorescence spectrometry (CVAFS): U.S. Geological Survey Techniques and Methods, book 5, chap. D2, 6 p. 


\section{Contents}

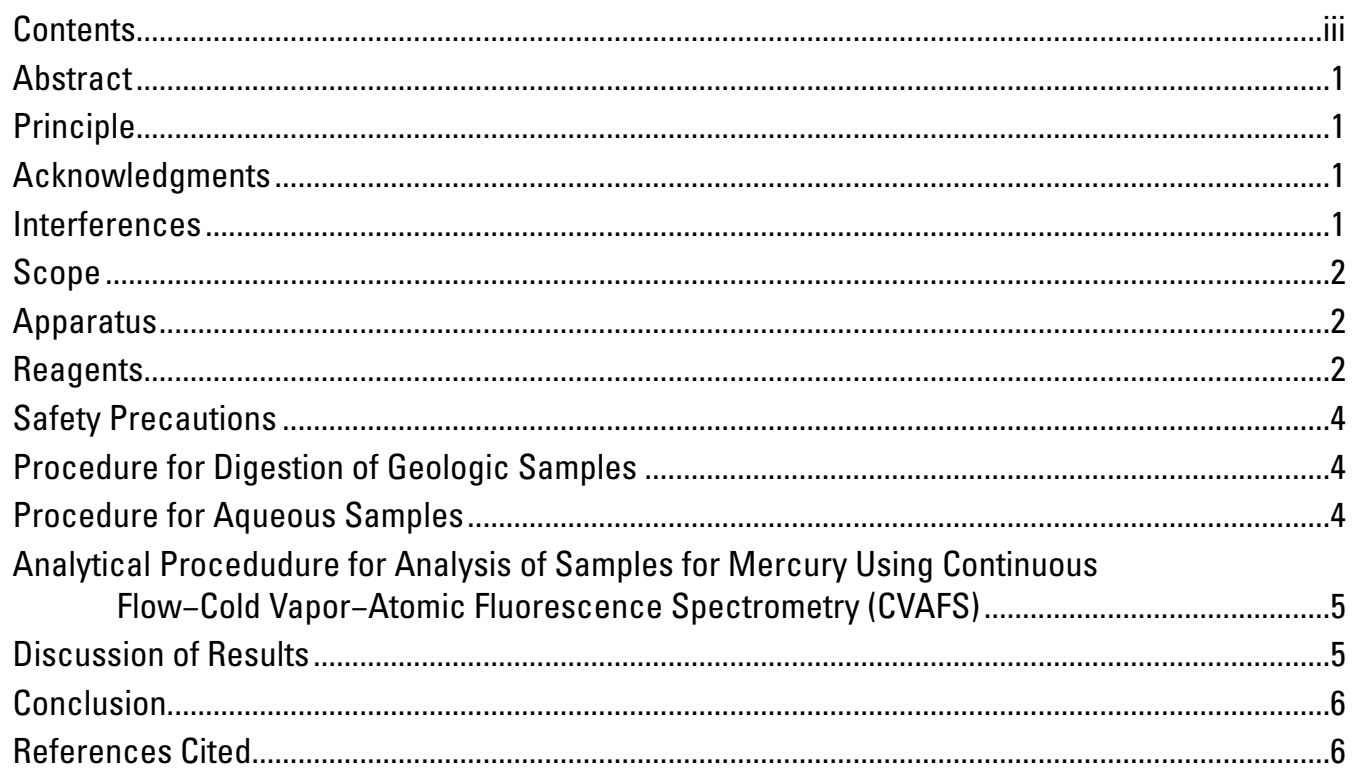

\section{Figures}

1. The Leeman HYDRA ${ }^{\circledR}$ cold vapor-atomic fluorescence spectrometry mercury analyzer with added incandescent heat lamp .....................................................................

2. Drilled aluminum heating block used for digestion of geologic matrices..........................

\section{Table}

1. Analytical performance summary for determination of mercury by continuous flow-cold vapor-atomic fluorescence spectrometry. 


\section{Conversion Factors}

\begin{tabular}{lcl}
\hline Multiply & By & To obtain \\
\hline centimeter $(\mathrm{cm})$ & Length & \\
millimeter $(\mathrm{mm})$ & $3.94 \times 10^{-1}$ & inch \\
micrometer $(\mu \mathrm{m})$ & $3.94 \times 10^{-2}$ & inch \\
\hline & $3.94 \times 10^{-5}$ & inch \\
\hline gram $(\mathrm{g})$ & Mass & ounce, avoirdupois \\
\hline & $3.53 \times 10^{-2}$ & gallon \\
\hline liter $(\mathrm{L})$ & Volume & gallon \\
milliliter $(\mathrm{mL})$ & $2.64 \times 10^{-1}$ & inch \\
microliter $(\mu \mathrm{L})$ & $2.64 \times 10^{-4}$ & inch \\
cubic centimeter $\left(\mathrm{cm}^{3}\right)$ & $2.64 \times 10^{-7}$ & \\
\hline
\end{tabular}

Degree Celsius $\left({ }^{\circ} \mathrm{C}\right)$ may be converted to degree Fahrenheit $\left({ }^{\circ} \mathrm{F}\right)$ by using the following equation: ${ }^{\circ} \mathrm{F}=9 / 5\left({ }^{\circ} \mathrm{C}\right)+32$

\section{Abbreviated water-quality units used in this report:}

$\mathrm{ng} / \mathrm{g} \quad$ nanogram per gram

$\mathrm{ng} / \mathrm{L} \quad$ nanogram per liter

$\mu \mathrm{g} / \mathrm{g} \quad$ microgram per gram

$\mu \mathrm{g} / \mathrm{L} \quad$ microgram per liter 


\section{The following abbreviations and symbols are used in this report:}

$\begin{array}{ll}\text { ASTM } & \text { American Society for Testing and Materials } \\ \text { CVAAS } & \text { cold vapor-atomic absorption spectrometry } \\ \text { CVAFS } & \text { cold vapor-atomic fluorescence spectrometry } \\ \text { DI } & \text { deionized } \\ M & \text { molarity (moles per liter) } \\ \text { MSDS } & \text { materials safety data sheet } \\ \text { N } & \text { normality (equivalents per liter) } \\ \text { NIST } & \text { National Institute of Standards and Technology } \\ \text { NWQL } & \text { National Water Quality Laboratory } \\ \text { ppb } & \text { parts per billion } \\ \text { ppt } & \text { parts per trillion } \\ \text { rpm } & \text { revolutions per minute } \\ \text { SRM } & \text { Standard Reference Material } \\ \text { USEPA } & \text { U.S. Environmental Protection Agency } \\ \text { USGS } & \text { U.S. Geological Survey } \\ \text { M } \Omega & \text { megohm } \\ \text { v/v } & \text { volume per volume } \\ \text { w/v } & \text { weight per volume } \\ \text { percent R } & \text { percent recovery } \\ > & \text { greater than } \\ \sim & \text { about }\end{array}$




\title{
Determination of Mercury in Aqueous and Geologic Materials by Continuous Flow-Cold Vapor-Atomic Fluorescence Spectrometry (CVAFS)
}

\author{
By Philip L. Hageman
}

\section{Abstract}

New methods for the determination of total mercury in geologic materials and dissolved mercury in aqueous samples have been developed that will replace the methods currently (2006) in use. The new methods eliminate the use of sodium dichromate $\left(\mathrm{Na}_{2} \mathrm{Cr}_{2} \mathrm{O}_{7} \cdot 2 \mathrm{H}_{2} \mathrm{O}\right)$ as an oxidizer and preservative and significantly lower the detection limit for geologic and aqueous samples. The new methods also update instrumentation from the traditional use of cold vapor-atomic absorption spectrometry to cold vapor-atomic fluorescence spectrometry. At the same time, the new digestion procedures for geologic materials use the same size test tubes, and the same aluminum heating block and hot plate as required by the current methods. New procedures for collecting and processing of aqueous samples use the same procedures that are currently (2006) in use except that the samples are now preserved with concentrated hydrochloric acid/bromine monochloride instead of sodium dichromate/ nitric acid. Both the "old" and new methods have the same analyst productivity rates. These similarities should permit easy migration to the new methods. Analysis of geologic and aqueous reference standards using the new methods show that these procedures provide mercury recoveries that are as good as or better than the previously used methods.

\section{Principle}

The digestion procedure for geologic materials is based on similar procedures that have been used for several years by the U.S. Environmental Protection Agency (USEPA) (2001).

In order to determine the total mercury concentration in geologic materials, samples are digested using a hot plate and a mixture of concentrated nitric acid $\left(\mathrm{HNO}_{3}\right)$ and concentrated hydrochloric acid $(\mathrm{HCl})$ in a ratio of $0.5 / 2.0 \mathrm{~mL}$, respectively. After digestion, all mercury in the sample is oxidized to $\mathrm{Hg}$ (II) using bromine monochloride $(\mathrm{BrCl})$. The digestate is diluted to $14.75 \mathrm{~mL}$ with ASTM Type I reagent water and pre-reduced with hydroxylamine hydrochloride $\left(\mathrm{NH}_{2} \mathrm{OH} \cdot \mathrm{HCl}\right)$ prior to analysis.
The methods described herein for the preservation, processing, and analysis of aqueous samples for mercury are modifications to those used for several years by the U.S. Geologic Survey (USGS) National Water Quality Laboratory (NWQL) (Garbarino and Damrau, 2001) and procedures used by the U.S. Environmental Protection Agency (2002).

For determination of dissolved mercury in aqueous samples, samples must be filtered $(0.45-\mu \mathrm{m}$ capsule filter) and preserved at the time of collection with $0.5 \mathrm{~mL}$ mercury-free concentrated hydrochloric acid per $30 \mathrm{~mL}$ of sample. The sample must be collected and stored in acid-washed borosilicate glass bottles with fluoropolymer lined caps. Upon return to the laboratory, samples must be further preserved and oxidized by the addition of $\mathrm{BrCl}$. This procedure preserves the samples for at least 5 months (Garbarino and Damrau, 2001).

For instrumental analysis of geologic and aqueous samples, $\mathrm{Hg}$ (II) is reduced to elemental mercury vapor $\left(\mathrm{Hg}^{0}\right)$ by mixing the sample with stannous chloride $\left(\mathrm{SnCl}_{2}\right)$ in a continuous flowcold vapor manifold. Elemental mercury vapor $\left(\mathrm{Hg}^{0}\right)$ is separated and purged from the solution with ultrapure argon, and mercury concentration is measured by atomic fluorescence spectrometry. Quality assurance is demonstrated through the analysis of blanks, replicates, and Standard Reference Materials (SRMs).

\section{Acknowledgments}

I would like to thank Sarah Stetson for help in developing these methods.

\section{Interferences}

Gold, silver, and iodide have been identified as interferences and have been shown to diminish the extraction efficiency and/or suppress the recovery of mercury from the sample when using these methods (Garbarino and Damrau, 2001; U.S. Environmental Protection Agency, 2002). Geologic samples containing $>10 \mu \mathrm{g} / \mathrm{g}$ or aqueous samples containing $>$ $100 \mu \mathrm{g} / \mathrm{L}$ of any of these constituents must be diluted prior to analysis to mitigate the potential interference. 
Water vapor condensation in the fluorescence detector is a major interference if allowed to develop. To avoid this problem, the operator must periodically check for condensation during the course of analysis and make sure that fresh drying agent (soda lime) is maintained in the in-line drying cell of the instrument. An adjustable lamp with a 150-watt incandescent bulb can also be placed in front of the reaction cell (fig. 1) of the instrument. This lamp can be turned on during analysis to keep the tubing and reaction cell warm, which helps inhibit the formation of condensation.

Finally, great care must be taken when collecting samples (all matrices) for mercury analysis because contamination of either the sample or the sampling equipment is possible due to the ubiquitous nature of mercury in the environment.

\section{Scope}

For solid-phase samples, this method offers a low reporting limit of $5 \mathrm{ng} / \mathrm{g}$ mercury. Samples exceeding the working range of 5 to $500 \mathrm{ng} / \mathrm{g}$ mercury must be redigested, diluted, and reanalyzed. For all aqueous samples, this method offers a lower reporting limit of $5 \mathrm{ng} / \mathrm{L}$. Samples exceeding the working range of 5 to $100 \mathrm{ng} / \mathrm{L}$ mercury must be diluted and reanalyzed. About 30 solid-phase samples can be analyzed per day with the digestion being the limiting factor. At least 40 aqueous samples can be analyzed per day.

Note that for the analysis of solid-phase or routine aqueous samples, the new detection limits are considerably lower than the cold vapor-atomic absorption spectrometry methods previously used. The old detection limits were $20 \mathrm{ng} / \mathrm{g}$ for solid samples and $0.10 \mathrm{ng} / \mathrm{g}$ for routine aqueous samples (Brown and others, 2002). Low-level mercury determinations in aqueous samples are currently (2006) being done using cold vapor-atomic fluorescence spectrometry and have a detection limit of $5 \mathrm{ng} / \mathrm{L}$ (Hageman, 2002). This means that for analysis of solid samples, the detection limit for the new procedure is four times lower than the method previously used, and for routine aqueous samples, the upper limit of the new procedure is equal to the lower detection limit of the old procedure. The lower detection limits will make it possible to determine mercury on a significantly higher percentage of the solid and aqueous samples submitted.

\section{Apparatus}

\section{- Vortex mixer}

- Leeman HYDRA ${ }^{\circledR}$ CVAFS Instrument with incandescent heating lamp (fig.1).

- Standard laboratory hot plate ( 30 by $60 \mathrm{~cm}$ ) that must be able to maintain a temperature of $90^{\circ} \mathrm{C}$.

- Drilled aluminum heating block (fig. 2) measuring 6.35 $\mathrm{cm}$ thick by $19.05 \mathrm{~cm}$ wide by $31.75 \mathrm{~cm}$ long that can be placed directly on top of hot plate and hold 5016 - by 100 $\mathrm{mm}$ disposable glass test tubes.

\section{Reagents}

Acids used for solids digestion are research grade. Acids used for aqueous analysis, and for making all reagents and calibration standards, are trace metal purified (distilled) and mercury free. All other chemicals used for these procedures are reagent grade unless specified. Deionized (DI) water is ASTM Type I reagent water (18-M $\Omega$ ) and is referred to in this report as reagent DI water. It is important to use the same source of reagent DI water for all processes and procedures described herein, because the use of water that has not been certified to be mercury free can be a major source of mercury contamination.

Glassware used for this method, including volumetric flasks used for making stock and calibration standards, bottles or flasks used for storage of $\mathrm{BrCl}$, and sampling bottles used for collection of aqueous samples, should be allowed to sit overnight filled with 10 percent mercury free hydrochloric acid, and then rinsed three times with reagent DI water. This procedure is referred to as "acid-washed" in this publication. To remain mercury free, all 16- by $100-\mathrm{mm}$ test tubes used for these methods should be kept in an oven at $90^{\circ} \mathrm{C}$ until needed.

\section{Note: All reagents must be prepared in a fume hood.}

Argon gas: Ultrapure (99.998 percent), with in-line dryer to dehumidify gas before it reaches instrument.

$0.2 N$ Bromine monochloride $(w / v)$ : In an acid-washed borosilicate glass or fluoropolymer bottle containing an acid-washed magnetic stir bar, dissolve $3.78 \mathrm{~g}$ potassium bromide $(\mathrm{KBr})$ in $350 \mathrm{~mL}$ concentrated hydrochloric acid $(\mathrm{HCl}, 12 \mathrm{M})$. Mix using a magnetic stirrer until totally dissolved. Slowly and carefully add $5.32 \mathrm{~g}$ potassium bromate $\left(\mathrm{KBrO}_{3}\right)$ and continue stirring until dissolved.

\section{Note: The addition of the $\mathrm{KBrO}_{3}$ results in a violent reac- tion with the evolution of free halogens.}

2 percent $\mathrm{HCl}(\mathrm{v} / \mathrm{v})$ : Dilute $20 \mathrm{~mL}$ concentrated $\mathrm{HCl}(12 \mathrm{M})$ to $1 \mathrm{~L}$ with reagent DI water.

10 percent $\mathrm{HCl}(\mathrm{v} / \mathrm{v})$ : Dilute $100 \mathrm{~mL}$ concentrated $\mathrm{HCl}(12 \mathrm{M})$ to $1 \mathrm{~L}$ with reagent $\mathrm{DI}$ water.

5 percent stannous chloride solution ( $w / v)$ : Dissolve $50.0 \mathrm{~g}$ stannous chloride $\left(\mathrm{SnCl}_{2} \cdot 2 \mathrm{H}_{2} \mathrm{O}\right)$ suitable for mercury analysis, in $50 \mathrm{~mL}$ concentrated $\mathrm{HCl}$. Allow to stand for 20 to 30 minutes until $\mathrm{SnCl}_{2}$ is totally dissolved. Dilute to $1 \mathrm{~L}$ with reagent DI water, cap, and shake. Allow the solution to clarify (1/2 hour) prior to use. When not in use, this reagent must be stored in the refrigerator $\left(\sim 5^{\circ} \mathrm{C}\right)$ until needed. If stored in this manner, reagent shelf life is at least 10 days.

15 percent hydroxylamine hydrochloride solution $(w / v)$ : Dissolve $15.0 \mathrm{~g}$ hydroxylamine hydrochloride $\left(\mathrm{NH}_{2} \mathrm{OH} \cdot \mathrm{HCl}\right)$ in $20 \mathrm{~mL}$ reagent $\mathrm{DI}$ water. After complete dissolution, bring to $100 \mathrm{~mL}$ with reagent DI water.

Instrument calibration standards: For solids analysis, calibration standards with $\mathrm{Hg}$ concentrations of 0.05, 0.100, 0.500, 1.00, 


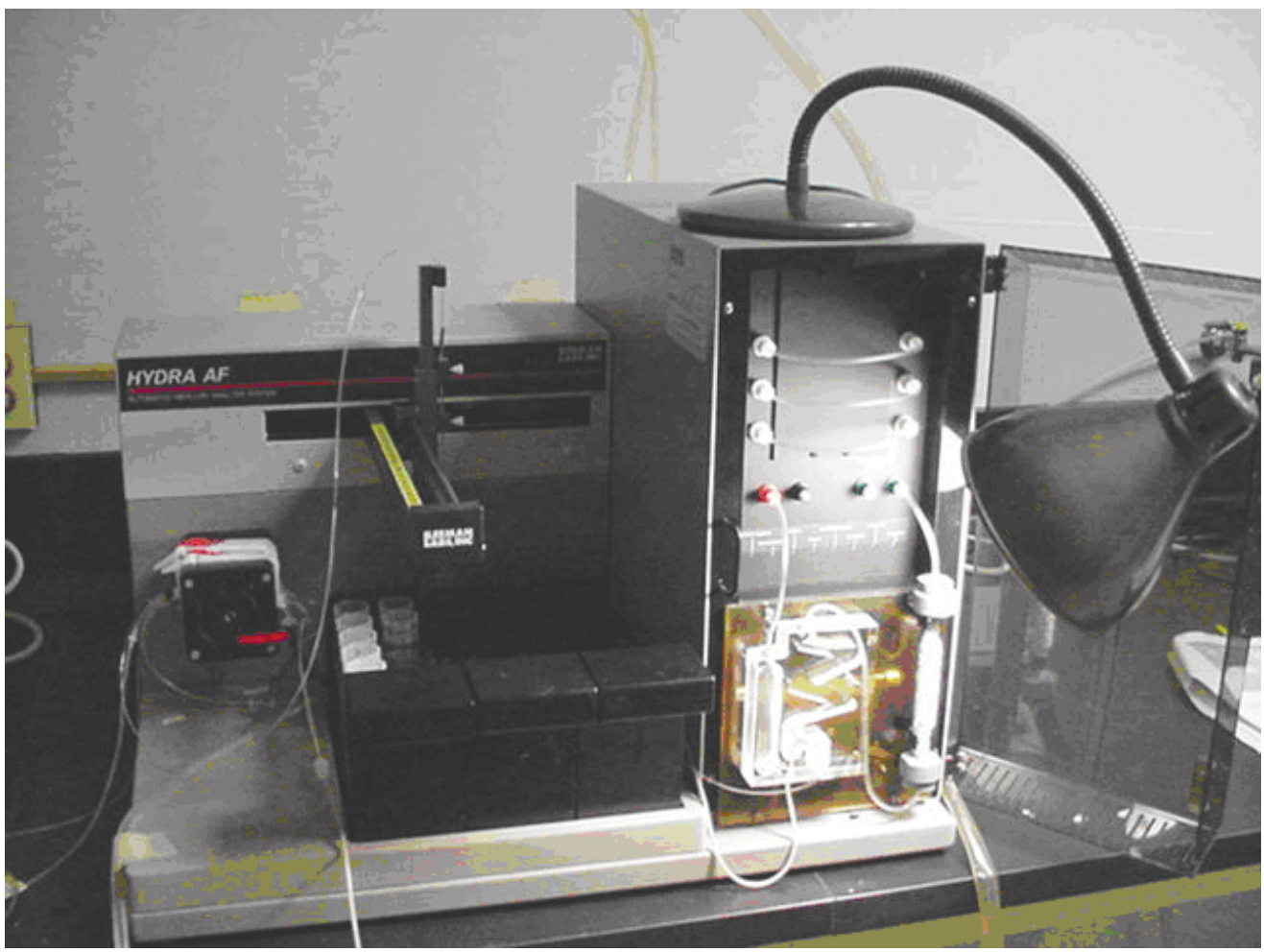

Figure 1. Leeman HYDRA ${ }^{\circledR}$ mercury analyzer with added incandescent heat lamp.

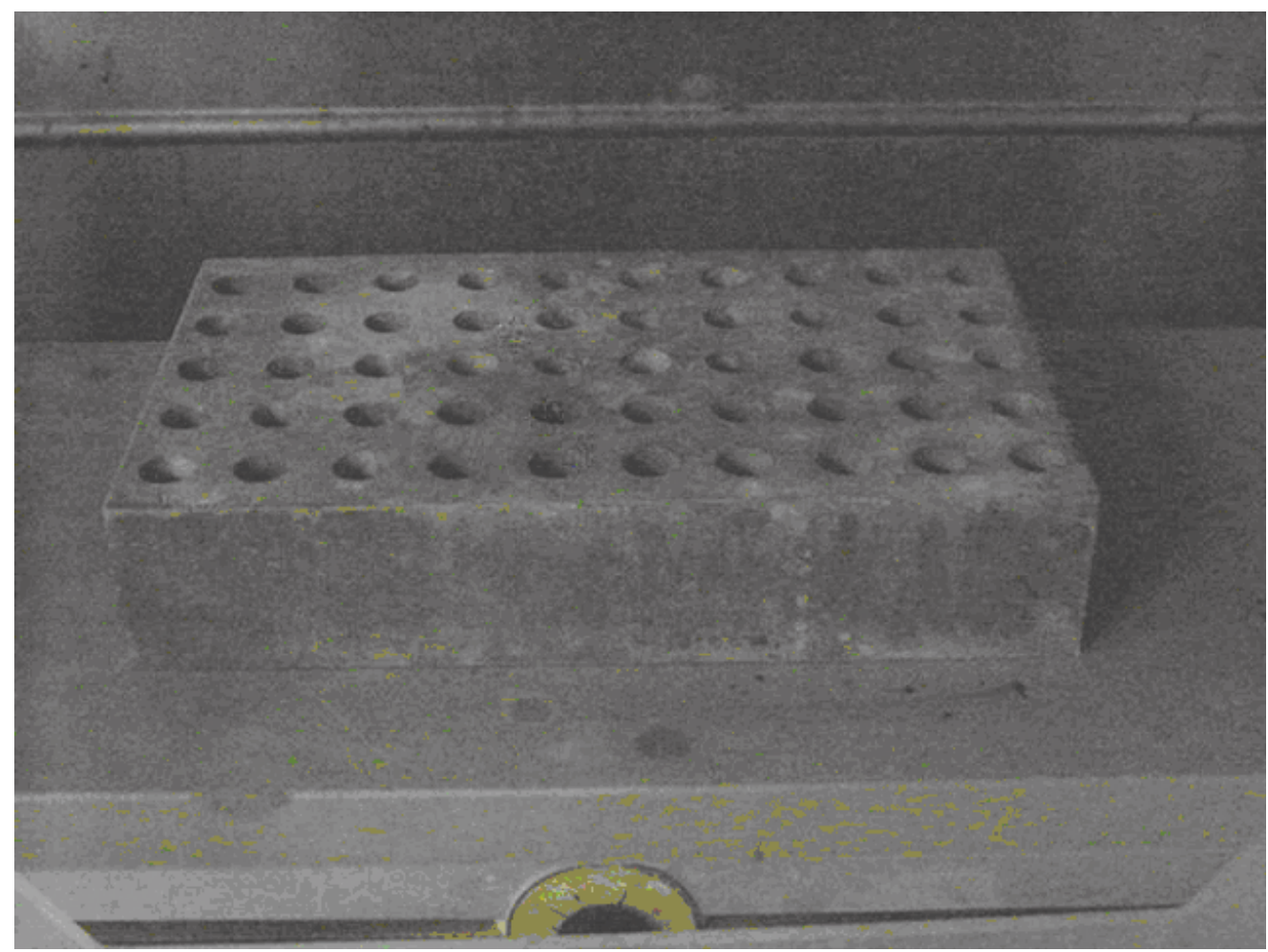

Figure 2. Drilled aluminum heating block used for digestion of geologic matrices. 
and $5.00 \mu \mathrm{g} / \mathrm{L}$ are made from serial dilution of a $100-\mu \mathrm{g} / \mathrm{L}$ stock solution [stock made from dilution of National Institute of Standards and Technology (NIST) 3133] in the following manner: In acid-washed 100-mL volumetric flasks, $0.05,0.10,0.50,1.0$, and $5.0 \mathrm{~mL}$ of the stock solution is added to separate flasks containing $0.5 \mathrm{~mL} 0.2 \mathrm{~N} \mathrm{BrCl}$. All flasks are diluted with reagent DI water to final volume (100 $\mathrm{mL})$, stoppered, and mixed.

For aqueous calibration standards, 5-, 10-, 50-, and 100-ng/L standards are prepared from serial dilution of a $1.0-\mu \mathrm{g} / \mathrm{L}$ stock solution (stock solution made from dilution of NIST 3133) as follows: In acid-washed $100-\mathrm{mL}$ glass volumetric flasks, 0.5 , $1.0,5.0$, and $10.0 \mathrm{~mL}$ of the stock solution is added to separate flasks containing $0.5 \mathrm{~mL} 0.2 \mathrm{~N} \mathrm{BrCl}$. All flasks are diluted with reagent DI water to final volume $(100 \mathrm{~mL})$, stoppered, and mixed.

The blank solution for solid and aqueous analyses is made by adding $0.5 \mathrm{~mL} 0.2 \mathrm{~N} \mathrm{BrCl}$ solution to an acid-washed 100-mL volumetric flask and diluting to volume with reagent DI water. Stock and calibration standards preserved with $\mathrm{BrCl}$ should be replaced every 3 months.

\section{Safety Precautions}

Observe normal laboratory safety procedures, including the use of protective eyewear, laboratory coat, and gloves. Perform all reagent mixing and chemical digestion activities in a chemical hood. See the Chemical Hygiene Plan (CHP) and Material Safety Data Sheet (MSDS) for further information concerning first-aid treatment and disposal procedures for chemical products used in this method. The atomic fluorescence spectrometer needs to be located under a vented exhaust hood so as to evacuate the acid gases and mercury vapors that are produced by the continuous flow-cold vapor system.

\section{Procedure for Digestion of Geologic Samples}

1. Weigh $0.100 \mathrm{~g}$ of sample into 16 - by 100-mm disposable borosilicate glass test tube.

2. Add $0.5 \mathrm{~mL}$ concentrated $\mathrm{HNO}_{3}(16 M)$ to test tube and mix with vortex to wet sample.

3. Add $2.0 \mathrm{~mL}$ concentrated $\mathrm{HCl}(12 \mathrm{M})$ (Add $\mathrm{HCl}$ in 0.5-mL aliquots to carbonate rich samples.)

4. Vortex and let samples react overnight.

5. Vortex samples and place into a room temperature aluminum heating block.

6. Turn hot plate on and heat samples (uncovered) for 2 hours at $90^{\circ} \mathrm{C}$.
7. Remove samples from hot plate and cool to room temperature.

8. Add $30 \mu \mathrm{L} 0.2 \mathrm{~N} \mathrm{BrCl}$ to all samples and vortex.

9. Dilute all samples to $15 \mathrm{~mL}(0.6 \mathrm{~cm}$ below top of test tube) with reagent DI water.

10. In order to analyze samples at a later time, cap, shake, and store samples (samples processed in this manner can be stored for at least 1 month before being analyzed).

11. Prior to analysis, add $60 \mu \mathrm{L} 15$ percent $\mathrm{NH}_{2} \mathrm{OH} \cdot \mathrm{HCl}$ to each tube. Cap and shake samples. Let samples stand until the particulate matter has settled. This can also be achieved by centrifuging the samples at $3,000 \mathrm{rpm}$ for 10 minutes.

12. Remove cap and place samples into the instrument's autosampler for analysis.

13. Any sample with mercury concentration exceeding the highest calibration standard $(500 \mathrm{ng} / \mathrm{g}$ in sample) must be redigested, diluted, and reanalyzed. After the sample has been redigested and processed using the procedures described above, dilute the digestate by taking a $1.5-\mathrm{mL}$ aliquot and adding it to a new 16 - by $100-\mathrm{mm}$ test tube containing 60 $\mu \mathrm{L} \mathrm{NH} \mathrm{N}_{2} \mathrm{OH} \cdot \mathrm{HCl}$. Bring to volume $(14.75 \mathrm{~mL})$ with reagent DI water. Cap and shake the sample, and reanalyze using the procedures described above.

\section{Procedure for Aqueous Samples}

Aqueous samples are filtered into acid-washed borosilicate glass bottles using a $60-\mathrm{cm}^{3}$ (cubic centimeter) syringe and a $0.45-\mu \mathrm{m}$ pore-size nitrocellulose filter. If filtration is difficult, a $0.70-\mu \mathrm{m}$ glass fiber pre-filter can be used in conjunction with the $0.45-\mu \mathrm{m}$ filter in a serial manner. Preserve the filtrate in the field or the laboratory by adding $0.5 \mathrm{~mL}$ concentrated, mercury free $\mathrm{HCl}(12 \mathrm{M})$ per $30 \mathrm{~mL}$ filtered sample. After preservation, store the bottles with caps that have fluoropolymer liners.

1. Upon arrival at the laboratory, add $60 \mu \mathrm{L} 0.2 \mathrm{~N} \mathrm{BrCl}$ to all samples. Following this, recap and shake all bottles. Samples preserved in this manner can be stored for up to 5 months.

2. Just prior to analysis, add $60 \mu \mathrm{L} 15$ percent $\mathrm{NH}_{2} \mathrm{OH} \cdot \mathrm{HCl}$ to all $16-$ by $100-\mathrm{mm}$ test tubes that will go into the autosampler, and bring the test tubes to volume $(14.75 \mathrm{~mL})$ with sample. Cap, shake, and let samples stand 5 minutes.

3. Use aqueous calibration standards of $0,5,10,50$, and $100 \mathrm{ng} / \mathrm{L} \mathrm{Hg}$ for analysis. Analyze samples 
using the same reagents and apparatus used for solids analysis.

4. Dilute and reanalyze any sample with mercury concentration exceeding the highest calibration standard (100 ng/L). To dilute the sample, take a $1.5-\mathrm{mL}$ aliquot from the original sample and add it to a new 16by $100-\mathrm{mm}$ test tube containing $60 \mu \mathrm{L} \mathrm{NH} \mathrm{NH}_{2} \mathrm{OHCl}$. Bring to volume $(14.75 \mathrm{~mL})$ with reagent DI water. Cap, shake, and let stand for 5 minutes.

\section{Analytical Procedure for Analysis of Samples for Mercury Using Continuous Flow-Cold Vapor-Atomic Fluorescence Spectrometry (CVAFS)}

Mercury determination is fully automated using a Leeman HYDRA AF ${ }^{\circledR}$ CVAFS mercury analyzer (fig. 1). Prepared or digested samples are uncapped and loaded into the instrument autosampler. The instrument is calibrated using matrix appropriate calibration standards, as explained in the previous section. For sample analysis, the instrument takes up a set volume of sample and mixes it with 5 percent $\mathrm{SnCl}_{2}$. This procedure results in any $\mathrm{Hg}$ (II) in the sample being reduced to $\mathrm{Hg}^{0}$. The solution is purged into the in-line phase separator of the instrument, and the liquid is separated from the mercury vapor. Ultrapure argon gas carries the vapor through a drying cell and introduces it into the fluorescence cell of the instrument. Mercury concentration is calculated by the instrument using the calibration curve and linear regression. Mercury concentration is reported in micrograms per kilogram for solids, and in nanograms per liter for aqueous samples.

\section{Discussion of Results}

As part of the validation process for the new methods, a series of reference standards and blanks were digested and analyzed using the described procedures. The results for analysis of the reference standards are listed in table 1.

Table 1. Analytical performance summary for determination of mercury by continuous flow-cold vapor-atomic fluorescence spectrometry (CVAFS)

[Mercury concentration for aqueous samples in nanograms per liter, solid-phase samples given in micrograms per kilogram; n, number of samples analyzed; s, standard deviation; pv, preferred value for the reference materials; Ref., Reference (footnote number); \% RSD, percent relative standard deviation; \%R, percent recovery; \%R (new), percent recovery achieved using CVAFS and the new methods described in this paper; \%R (old), percent recoveries achieved using CVAAS and the old dichromate method; \pm , plus or minus; - -, not applicable]

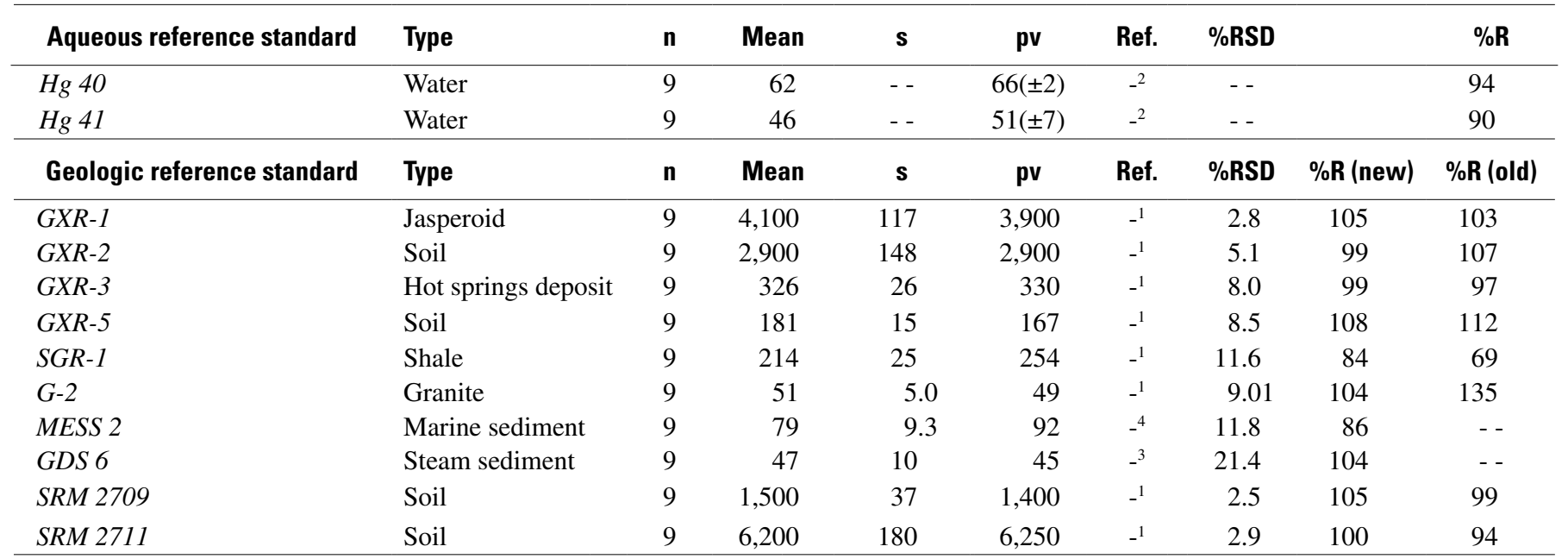

Method blank results

\begin{tabular}{lcccccc} 
Method blank & $\mathbf{n}$ & Mean & s & 3s & 5s \\
\hline Aqueous method & 9 & 1.63 & 0.56 & 1.68 & 2.80 & .065 \\
Geologic method & 9 & .071 & .013 & .039 & .065 \\
\hline
\end{tabular}

${ }^{1}$ Brown, and others (2002).

${ }^{2}$ U.S. Geological Survey (2006).

${ }^{3}$ Govandaraju (1994).

${ }^{4}$ Govandaraju (1989). 
Ten geologic reference standards were processed, digested, and analyzed using the methods described in this report. These standards represent a wide variety of geologic matrices. Percent recoveries for the six reference standards ranged from 84 to 108 percent. Also listed in table 1 are the percent recoveries for the same reference materials that were digested and analyzed by the old procedures, which included the use of sodium dichromate (Brown and others, 2002). Two samples, MESS 2 and GSD 6, were not reported using the old procedure and thus no percent recoveries are listed for these materials.

Two aqueous reference standards were analyzed using the new procedures, and percent recoveries for the two samples were 94 and 90 percent, respectively. These reference samples were not preserved with dichromate so that no comparison can be made with the method that was previously used.

Overall, the new methods (geologic and aqueous) produce recoveries as good as, or better than, the dichromate methods that were previously used.

Blanks were digested and analyzed as part of the validation of the new procedures. Blanks for aqueous samples and solidphase samples were taken through all the procedures described herein and analyzed using CVAFS. Data for the blanks are listed in table 1 . The value represented by three standard deviations is considered to be the lower limit of detection, and the value represented by five standard deviations is considered to be the lower limit of determination for the new methods.

\section{Conclusion}

New digestion and analytical methodology have been designed and tested for the determination of total mercury in geologic materials, and dissolved mercury in aqueous samples. These methods have been designed to replace the methods and procedures that are currently in use (2006) for these matrices. This study indicates that the new methods offer significant improvements over the procedures currently in use. The new methods eliminate the use of sodium dichromate as an oxidant and preservative, replacing it with concentrated hydrochloric acid and bromine monochloride. Eliminating the dichromate will result in a substantial cost savings because it will not have to be collected, stored, and disposed of as hazardous waste. The use of hydrochloric acid is also safer, less restrictive, and less expensive to ship to or from the field.

The new methods offer lower detection limits for solids and aqueous samples and update the instrumentation used for analysis. These improvements are achieved by replacing the traditional use of cold vapor-atomic absorption spectrometry (CVAAS) with cold vapor-atomic fluorescence spectrometry (CVAFS) for geologic and all aqueous samples, thus eliminating the two-tier system of analysis for aqueous samples, which previously required analysis by CVAAS and CVAFS.

The new methods will result in an increase in laboratory capacity and promote efficiency of the operator/analyst because a higher percentage of the submitted samples will be quantified for mercury. Benefit and production increases also will be seen by the submitter/investigator due to the generation of more geochemical data and increased sampling efficiency.

Finally, the new digestion procedures for geologic materials have been designed to use the same size test tubes, aluminum heating block, and hot plate as the current methods (2006) require. For aqueous samples, the new method for collection and processing require the use of the same collection procedures and equipment as have been used traditionally except that the samples are preserved with concentrated hydrochloric acid instead of sodium dichromate. Ultimately, for geologic and aqueous samples, these similarities will allow for relatively simple changeover to the new methods, and once implemented, the new methods will enhance, simplify, and provide substantial cost savings over the old methods.

\section{References Cited}

Brown, Zoe Ann, O'Leary, R.M., Hageman, P.L., and Crock, J.G., 2002, Mercury in water, geologic, and plant materials by continuous flow-cold vapor-atomic absorption spectrometry, in Taggart, J.E., Jr., Analytical methods for chemical analysis of geologic and other materials: U.S. Geological Survey Open-File Report 02-0223, Chapter M.

Garbarino, J.R., and Damrau, D.L., 2001, Methods of analysis by the U.S. Geological Survey National Water Quality Laboratory-Determination of organic plus inorganic mercury in filtered and unfiltered natural water with cold vapor-atomic fluorescence spectrometry: U.S. Geological Survey Water Resources Investigations Report 01-4132, 16 p.

Govandaraju, K., ed., 1989, 1989 Compilation of working values and sample description of 272 geostandards: Geostandards Newsletter, v. 13, Special Issue, 67 p.

Govandaraju, K., ed., 1994, 1994 Compilation of working values and sample descriptions for 383 geostandards: Geostandards Newsletter, v. 18, Special Issue, 158 p.

Hageman, P.L., 2002, Mercury in water samples by flow injection-cold vapor-atomic fluorescence spectrometry, in Taggart, J.E., Jr., Analytical methods for chemical analysis of geologic and other materials: U.S. Geological Survey Open-File Report 02-0223, Chapter N.

U.S. Environmental Protection Agency, 2001, Appendix to Method 1631: Total mercury in tissue, sludge, sediment, and soil by acid digestion and $\mathrm{BrCl}$ oxidation: EPA 821-R01-013, 2001, 13 p.

U.S. Environmental Protection Agency, 2002, Method 1631, Revision E: Mercury in water by oxidation, purge, and trap, and cold vapor-atomic fluorescence spectrometry: EPA 821-R-02-019, 2002, 38 p.

U.S. Geological Survey, 2006, Standard reference samples, Office of Water Quality, Branch of Quality Systems, Standard Reference Sample Project, accessed January 24, 2007, at URL http://qadata.cr.usgs.gov/srs_study/reports/index.php 


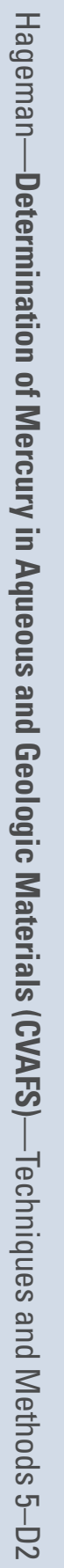

